Tavill, A.S., Evanson, J.M., Baker, S.B. \& HewitT, V. (1964) Idiopathic paroxysmal myoglobinuria with acute renal failure and hypercalcemia. New England Journal of Medicine, 271, 283.

Turkington, R.N., Delcher, H.K., Neelon, F.A. \& GitelMAN, H.J. (1968) Hypercalcemia following acute renal failure. Journal of Clinical Endocrinology and Metabolism, 28, 1224.
Wilson, R., Raposo, C., Venkatesan, R., Lin, R., Thompson, A., Guha, A., Kramer, N. \& Parrish, A.E. (1973) Hypercalcemia during the diuretic phase of acute renal failure. Medical Annals of the District of Columbia, 42, 327.

Wu, B.C., Pillay, V.K., Hawker, C.D., Armbruster, K.F., SHAPIRO, H.S. \& ING, T.S. (1972) Hypercalcaemia in acute renal failure of acute alcoholic rhabdomyolysis. South African Medical Journal, 46, 1631.

\title{
Acute renal failure and hypoglycaemia due to sulphadiazine poisoning
}

\author{
A. W. CRafT \\ M.B. B.S., M.R.C.P. \\ J. T. BROCKLEBANK \\ M.B. B.S., M.R.C.P. \\ R. H. JACKSON \\ M.A., B.M., B.Ch., F.R.C.P. \\ Department of Child Health, Royal Victoria Infirmary, Newcastle upon Tyne NE1 4LP
}

\begin{abstract}
Summary
A 3-year-old girl is described who became oliguric and hypoglycaemic whilst receiving an excessive dose of sulphadiazine. The mechanism of the hypoglycaemia is discussed.
\end{abstract}

\section{Introduction}

Acute renal failure due to sulphonamide administration is now uncommon. This report describes a patient who became oliguric and hypoglycaemic whilst receiving treatment with an excessively high dose of sulphadiazine for meningococcal septicaemia.

\section{Case report}

A 3-year-old girl weighing $13 \mathrm{~kg}$ was admitted to another hospital, having been generally unwell for $12 \mathrm{hr}$, and then became comatose and developed a purpuric rash. Meningococcal septicaemia was subsequently proved when the organism was grown from the blood, but not from the cerebrospinal fluid. She was treated with i.v. fluids, hydrocortisone, penicillin and sulphadiazine $(450 \mathrm{mg} / \mathrm{kg}$ bodyweight $/ 24 \mathrm{hr}$ ). Her condition improved over the next $48 \mathrm{hr}$ and the dose of sulphadiazine was reduced

Correspondence: Dr A. W. Craft, Department of Child Health, The Royal Victoria Infirmary, Newcastle upon Tyne NE1 4LP. to $300 \mathrm{mg} / \mathrm{kg} / 24 \mathrm{hr}$. Urine output, having been normal, was noted to be much less on days 4 and 5 and because of the appearance of haematuria, the sulphadiazine was stopped. The blood urea was $12 \mathrm{mmol} / \mathrm{l}$ but the following day rose to $30 \mathrm{mmol} / 1$ and she was transferred to this hospital for further management. On admission she was found to be oedematous and semi-conscious. The blood urea was $30 \mathrm{mmol} / 1$, the sugar less than $1 \mathrm{mmol} / \mathrm{l}$, plasma insulin $22 \mathrm{mu} . / \mathrm{ml}$, plasma cortisol $800 \mathrm{nmol} / \mathrm{l}$ and the blood sulphonamide $700 \mathrm{mg} / \mathrm{l}$ (therapeutic level $120 \mathrm{mg} / \mathrm{l}$ ). Urine examination showed red cells and typical sulphadiazine crystals. She did not regain consciousness after infusion of $10 \mathrm{~g}$ of glucose. Peritoneal dialysis was commenced and her clinical condition slowly improved, the blood urea, glucose and sulphonamide levels reverting to normal as in Fig. 1. However, her urine output did not improve and cystoscopy revealed aggegations of sulphonamide deposits around both ureteric orifices. Bilateral ureteric catheters were inserted and a $2.5 \%$ sodium bicarbonate solution was infused at the rate of $2.5 \mathrm{ml} / \mathrm{hr}$ in each renal pelvis. Shortly afterwards, she began to pass large volumes of urine, the catheters were removed and she continued with an uneventful convalescence from her illness. At followup 2 months later she was physically and mentally normal, a ${ }^{51} \mathrm{Cr}$-EDTA clearance was $120 \mathrm{ml} / \mathrm{min} /$ $1.73 \mathrm{~m}^{2}$ and i.v. pyelogram was normal. 


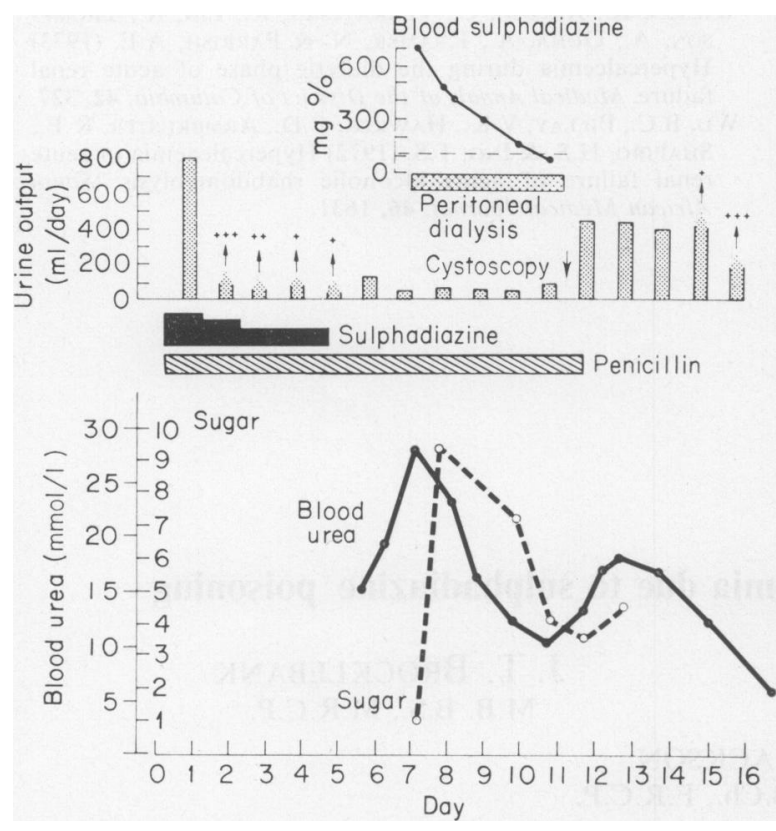

Fig. 1. Clinical data, laboratory results and treatment of the patient.

\section{Discussion}

Anuria due to sulphonamides has been attributed to direct renal toxicity, to a hypersensitivity reaction or to an obstructive uropathy due to precipitation of insoluble crystals in the urinary tract (Merril, 1971). The findings on cystoscopy in this patient, and the prompt diuresis which occurred when the crystals were removed, suggest that the anuria was due to the latter mechanism as in a similar case recently reported by Winterborn and Mann (1973). Dorfman and Smith (1970) have reviewed the urological aspects of this problem. Hypoglycaemia was an unexpected finding and its association with an inappropriately elevated plasma insulin level suggests that there may have been direct stimulation of the beta cells of the pancreas by the high levels of sulphadiazine in the blood. Hypoglycaemia may occur in diabetic patients treated simultaneously with sulphonamides and a sulphonyl urea compound (Christensen, Hansen and Kristensen, 1963), but occurs rarely due to sulphonamides alone, there being only one previous report of a child becoming hypoglycaemic after taking sulphonamides (Alain et al., 1966). An alternative explanation for the hypoglycaemia is that high levels of sulphadiazine may have interfered with the glucose oxidaseperoxidase method used for the estimation of the blood sugar, as may occur in some cases of paracetamol poisoning (Burn, 1973). This is unlikely as Sharp (1972) found no interference between sulphadiazine and the 'GOD-Perid' method of glucose determination used by the present authors. The dose of sulphadiazine given to the patient presented in this report was very high and if sulphonamides do have a place in the therapy of bacterial infections, then a soluble preparation, e.g. sulphadimidine, should be used in a maximum dose of $150 \mathrm{mg} / \mathrm{kg} /$ $24 \mathrm{hr}$, and the maintenance of a high urine flow rate is recommended (Weinstein, 1970).

\section{Acknowledgments}

We thank Dr G. Dale for his advice, Dr P. Smith for the sulphonamide assays and $\mathrm{Mr}$ J. E. S. Scott for performing the cystoscopy.

\section{References}

Alain, J., Caron, J., Huault, G., Cabanes, J., Joly, C. Aussannaire, M. (1966) Un cas d'intoxication par absorps tion massive de sulphaméthoxydiazine. Presse Médicalé, 74, 2363.

BURN, R. (1973) Blood glucose in paracetamol poisioning Lancet, i, 728.

Christensen, L.K., Hansen, J.M. \& Kristensen, M. (1963) § Sulphaphenazole-induced hypoglycaemic attacks in tolbutamide-treated diabetics. Lnacet, ii, 1298.

DorfmaN, L.E. \& SMITH, J.P. (1970) Sulfonamide crystalluria: a forgotten disease. Journal of Urology, 104, 482.

MerRIL, J.P. (1971) In: Diseases of the Kidney (Ed. by M. Strauss and L. G. Welt), 2nd Edn, Vol. 1, p. 644. Little Brown, Boston.

SHARP, P. (1972) Interference in glucose oxidase peroxidase blood glucose methods. Clinica chimica acta, 40, 115.

Weinstein, L. (1970) In: The Pharmacological Basis of 3 Therapeutics (Ed. by L. S. Goodman and A. Gilman), 4th Edn, p. 1177. Macmillan, New York.

WinterboRN, M.H. \& MANN, J.R. (1973) Anuria due to sulphadiazine. Archives of Disease in Childhood, 48, 915. 